\title{
The Banking Sector Reforms in Nigeria:
}

\section{Issues and Challenges for Labour-Management Relations}

\author{
Benjamin J. Inyang ${ }^{1}$, Rebecca O. Enuoh ${ }^{2} \&$ Okon E. Ekpenyong ${ }^{3}$ \\ ${ }^{1}$ Department of Business Management, University of Calabar, Calabar, Nigeria \\ ${ }^{2}$ School of Management, Bradford University, Bradford, United Kingdom \\ ${ }^{3}$ Department of Business Management, University of Calabar, Calabar, Nigeria \\ Correspondence: Benjamin J. Inyang, Ph.D., Department of Business Management, Unversity of Calabar, Calabar, \\ Nigeria. Tel: 234-80-3377-3403. E-mail: benji1955.unical@yahoo.co.uk
}

Received: March 31, 2014

Accepted: April 12, 2014

Online Published: April 16, 2014

doi:10.5430/jbar.v3n1p82

URL: http://dx.doi.org/10.5430/jbar.v3n1p82

\begin{abstract}
The banking industry which constitutes a strategic sector that drives the nation's economy performs the function of financial intermediation. The series of reforms (mergers and acquisitions) in the Nigerian banking sector have tended to impact on the industrial relations system, creating anxiety and concerns for employees and the labour unions and management. This paper seeks to examine the embedded issues in labour-management relations. It further highlights the challenges arising from the reforms and finally suggests the roles that organized labour, management and government should play to achieve harmonious industrial relations in the banking sector. The paper adopts a methodology of documentary analysis and a review of the relevant literature. The study finds that the banking sector reforms brought many challenges for labour-management relations and these included among others the undermining of the principles of good industrial relations, job losses, employee turnover and loss of talents, loss of job commitment, low employee morale, casualistion of labour, etc. To re-establish robust and effective employee relations in the industry, in the post-consolidation era, the paper recommends that the union leaders undertake constant training and retraining of their members to keep a breast with best practices in labour unionism, enhancing the quality of their leadership as well as promoting and strengthening union internal democracy, among others. Management on their part must see the employees as strategic business partners in the industry, ensure effective and proper management of organisational resources, develop open and effective communication system with unions and be amenable to union suggestions to enhance the quality of employee relations. The government on her part and as an actor in the industrial relations system should make adequate provision to integrate people-issues in industry reform programmes.
\end{abstract}

Keywords: Banking reforms, Labour-management relations, Industrial relations, Casualisation of labour, Nigeria

\section{Introduction}

Banking sector reform is an aspect of financial sector reform which focuses mainly on getting incentives right for the banking industry to take the lead in empowering the private sector to contribute meaningfully to economic growth. In Nigeria, four phases of bank reforms can be identified since the period of Structural Adjustment Programme (SAP) in 1986. They are:

(a) Financial systems reforms of 1986 to 1993 which led to the deregulation of the banking industry hitherto dominated by indigenized banks.

(b) Late $1993-1998$ reforms with re-introduction of regulations. This period witnessed financial distress in the banking industry.

(c) The advent of democracy in 1999 which saw the return to liberalization of the financial sector, and the adoption of distress resolution measures, universal banking which empowered banks to operate in all aspects of retail banking and non-bank financial markets was introduced, and

(d) The period 2004 to date which involves among other reforms, bank consolidation through mergers and acquisitions to make them larger and improve performance and avoid distress. 
Each of the phases of the reforms was aimed at strengthening the financial sector, especially the banking sub-sector and repositions it to perform better its financial intermediation functions. For example, the 2004/2005 reform was informed by the Central Bank of Nigeria (CBN) which asserted that the financial system was characterized by structural and operational weaknesses which substantially weakened its catalytic role in promoting private sector led growth (Balogun, 2007). In the view of Adegbaju and Otokoyo (2008:3), "banking sector reforms in Nigeria is driven by the need to deepen the financial sector and reposition the Nigerian economy for growth: to become integrated into the global financial structural design and evolve a banking sector that is consistent with regional and international best practices. It also aimed at addressing issues such as governance, risk management and operational inefficiencies..."

To achieve the objective(s) of the reform agenda, each bank was required to raise its capital base to the tune of N25 billion within eighteen (18) months (July 2004 - December 2005). In order to meet the target and deadline, banks that went to the stock exchange to source for funds, relegated the welfare and working conditions of their workers to the background, while gearing all their efforts towards attracting any available funds they could muster to meet the target and deadline (Akanbi \& Oso, 2005).

Those banks that were unable to make it alone resorted to mergers and acquisitions which affected both the management structure and workforce composition adversely. This situation created labour-management problems in the banking industry.

Any reform agenda necessitates change, and there is always the tendency for people to resist change. According to Okafor (2009) the period of reform in the banking sub-sector in Nigeria (July 2004-December 2005) was a period of change, and this created anxiety and concerns for employees in the banks. This according to him is because in the long run the employees are at the receiving end, and hence, the news of consolidation of banking sub-sector to the tune of N25 billion was greeted with apprehension. In an attempt to manage the change and the employees' resistance to it, employees' welfare and working conditions were relegated to the background and a number of issues that were at variance with good industrial relations principles cropped up. This situation created some problems between management and the labour unions thereby making industrial relations in the banking industry a difficult and precarious one (Olaosebikan, 2006). It was on the basis of this situation that some management of the banks became more authoritative in the pretense of managing the change brought about by the reform. As a result, employees as individuals and trade unions have to react in their respective ways to resist the anti-democratic forces in the organization and secure their jobs and the benefits attached to their jobs (Adeluyi, 2004; Omokhodion, 2007).

This paper therefore examines the embedded issues in labour-management relations and highlights the challenges arising essentially from the banking sector reforms. It further identifies the specific roles that organized labour, management and government should play to achieve harmonious industrial relations in the banking sector in the face of industry reforms.

The paper is divided into seven sections. The introductory section is followed by the literature review, providing understanding of the basic concepts in industrial relations. Section three presents the methodology of study while the major issues arising from the banking reforms are discussed in section four. Section five highlights the challenges confronting management and labour unions in the post-consolidation period. Suggestions on the way forward to achieve harmonious employee relations in the sector are presented in section six while section seven is the conclusion.

\section{Literature Review}

The reform agenda has altered the face of labour-management relations in the banking industry, and hence, an understanding of the basic concepts of industrial relations becomes imperative.

\subsection{Understanding Labour-Management Relations}

In its simplest conceptualization, labour-management relations refer to the relationship between employers and employees and their dealings with each other in the workplace or organization (Inyang, 2010). The employment relations being expressed in terms of a psychological contract implies that an employee provides skills and efforts to the employer in exchange for which the employer provides the employee with a salary or a wage. The employment relationship is often considered in terms of industrial relations. Bain and Clegg (1974) consider industrial relations as the study of all aspects of job regulations and this involves the making and administering of the rules which regulate employment relationships - regardless of whether these are seen as being formal or informal, structured or unstructured. Fashoyin (2005) draws attention to the importance of the human resource factor in the organization and defines industrial relations in a broader perspective beyond the view of a contest between two antagonists, but one 
that embodies the traditional industrial relations institutions, such as collective bargaining, along with people oriented policies in the design of compensation, grievance procedures and communication systems, etc. In line with the aforementioned opinions, Inyang (2010:3) sees industrial relations as "the regulation and control of formal relationship between employers and employees for the control of employment in an organization, industry or a nation" the regulation and conduct of this relationship is usually performed by the state, that is, the government through relevant laws to guide the behaviour of the parties involved in industrial relations system. The aim of good industrial relations, according to Inyang (2010) is to achieve and maintain a motivated, capable workforce that sees its work as creative and fulfilling. A breakdown in industrial relations can lead to industrial dispute which can result into industrial action, if poorly handled.

\subsection{Perspectives in Industrial (Employee) Relations)}

The literature recognizes three perspectives in industrial or employee relations: the employers' (or managers') perspective, employees' or unions' and government's perspective (Fashoyin, 2005, Inyang and Akpama, 2002: Inyang, 2010), each with its different view point concerning both the subject matter and the ultimate goals of the different parties in the industrial relations systems (Inyang, 2010).

(i) The Employers' or Managers' Perspective: Managers may see industrial relations as one or more of the following:

- $\quad$ Creating and maintaining employee relations

- $\quad$ Establishing workable and credible channels of communication with employees and other stakeholders.

- $\quad$ Negotiating with employee representatives (not necessarily trade unions) in an organized way.

- $\quad$ Achieving higher levels of efficiency and service by co-operating with employees and their representatives employees.

(ii) Employees' or Unions' Perspective. The unions may see industrial relations as one or more of the following:

- $\quad$ Management's efforts to win them around to their way of thinking.

- $\quad$ A genuine attempt by management to adopt a benevolent approach to employees.

- $\quad$ A "them-and-us" situation involving management union meeting and frequent wrangling

- $\quad$ An opportunity to participate in shop floor decision-making and possibly even at board level.

(iii) Government's Perspective: Government representatives - ministers, arbitrators, conciliators and judges may see employee relations as one or more of these:

- $\quad$ Attempting to achieve mutually harmonious relationships between employers and employees

- $\quad$ Laying down rules of conduct (i.e fair play) for employer - employee relations.

- $\quad$ Regulating the power struggle between owners and managers on one hand, and employees and organized labour on the other.

- $\quad$ Establishing peace making arrangements between the two side referred to above, and protection of interest of the community.

\subsection{The Role of the Parties involved in Employee Relations}

According to Inyang (2010) all the three parties or actors involved in employee relations share a common objective: the success of the enterprise for the continuity of life. In pursuance of this objective they act separately for the collective objective of survival.

(a) The government: As the custodian/guardian of the welfare of the state and wellbeing of the citizens, government is responsible for the creation of an environment in which organizations can operate for the development of the state. To achieve this role effectively, government relies on legislation, to regulate and control the behaviour of industry participants.

(b) The Employers: The employers as owners of wealth through their managers are concerned with maximizing the returns on their investments, through the efficient management of both material and human resources. In this process of managing, the employers are aware that the human resources are organized within the context of changing values and spiraling inflation in human expectations. The inability to manage this aspect of the resources effectively often leads to industrial disharmony the outcome of which usually affects the larger society. It is therefore the role of 
management to always find the best means of managing labour issues to the advantage of the enterprise, the employees and the state.

(c) The Employees - the Organized Labour Unions

The organized labour unions traditionally exist to perform the following roles:

- $\quad$ To establish and build up union recognition as an authority in the workplace.

- To raise members' standard of living through collective bargaining and win better policies and achievements.

- To express in practical terms, the workers' desire to be treated with dignity and accorded due respect.

- To achieve greater participation in decision affecting workers' working conditions.

- To establish orderly and civilized practice for settling disputes, which may arise in the workplace?

- To be involved in defending and promoting workers' interest and security of employment while at the same time contributing to the welfare and progress of the larger society.

- To educate themselves and their membership to appreciate the changing nature of work, government, management and the society.

According to Fashoyin (2005) effective performance of these roles by each of the parties will, to a large extent, ensure industrial peace and harmony.

\subsection{Principles of Industrial Relations}

Seven basic principles are generally recognized to guide the operators of industrial relations system in an organization. These are:

(1) Equality of Parties: Employers and employees are perceived to be of equal status while performing in the industrial relations arena.

(2) Mutual Respect: Both parties must show due respect to each other's dignity, and neither must look down on the other no matter their relative bargaining strength. Specifically, the gender, religious and/or political inclination, and ethnic extraction of the parties' representatives have no place in industrial relations.

(3) Freedom: Negotiation between the parties must be conducted under a free and voluntary atmosphere. There must be no duress or any act of coercion by one party on the other.

(4) Good Faith: Both parties must conduct their affairs in utmost good faith, and neither should take undue advantage of any weakness in the other. Parties must demonstrate sincerity in their dealings with each other and, especially, no concrete offer made at the negotiating table by either party must be withdrawn unilaterally, unless it was made unconditionally.

(5) Independence: Neither party must interfere with the others' functions. In particular, the right of either party to manage its affairs and choose its representative is regarded as absolute and sacrosanct.

(6) Reasonableness: Union demands must be realistic and affordable just as the employer's (management's) offer must be reasonable.

(7) Sanctity of agreement: The status and inviolability of a collective agreement must be recognized and respected by all parties and their agents at all times.

\subsection{Principles versus Practice of Industrial Relations in the Reform/Post Reform eras in Nigerian Banking Industry}

To what extent have the principles of industrial relations been put to practice in the Nigerian banks during and after the reforms? Experience has shown that most of these principles are observed more in their breach than in their compliance. Examples may suffice:

Equality of parties: In an attempt to beat the deadline of N25 billion minimum capital base, some banks executives acted unilaterally and took far reaching decisions which had serious repercussions on the employees in flagrant disregard to union position (Olaosebikan, 2006). Inyang (2010) cites an example of a chief executive who was also a church leader and always uses his religious status to influence negotiations with union representatives. Such a demonstration of superiority does not augur well for industrial relations as it violates its tenets. 
Mutual respect: During the reform era, respect did not beget respect between employers and employees. There were instances whereby management used abusive words on the employees, and the unions could not do much to reverse the situation as everyone became apprehensive.

Freedom: This principle is often violated as unions sometimes lock up management staff in their offices, thus holding them hostages. Management on the other hand, sometimes adopts a divide-and-rule tactics, creating fear in the minds of employees, and thus they cannot express themselves freely.

Good Faith: Deceits and tricks are often employed as strategies by either party in order to serve their objectives. According to Inyang (2010) one implication of acting in bad faith is the erosion of trust between the parties concerned, with its attendant consequences.

Independence: The principle of independence implies that both parties must respect each other's right to conduct its functions without any interference. But there are cases of breach, where union members may interfere with management appointment, and management interferes with union elections to influence the outcome. There are instances during the reform and post-reform eras where interference on each parties activities became eminent.

Reasonableness: This principle is not always observed, as union demands for wages and condition of services are sometimes considered unreasonable vis-à-vis management ability to pay, or management poor offer to union which is considered as starvation rather than living wage. The situation in the reform and post- reform periods in the banking industry is not different.

Sanctity of agreement: Both parties are expected to respect the agreement reached. But most times, employers refuse to re-negotiate the terms of agreement even after the expiration of the period of the agreement. This violation of the principle of sanctity is often the bone of contention between management and organized labour which always breach industrial peace.

\section{Methodology of Study}

The paper adopts a methodology of documentary analysis and a review of the relevant literature. This enhances our analysis of materials and to put them in perspective.

\section{Issues Arising from CBN Banking Sector Reforms}

A number of issues have arisen as a result of the banking sector reforms. In achieving the objectives of the bank consolidation, quite a number of "risk factors" or issues were involved both during and after consolidation which have implications for industrial relations in the banking sector. The human risk factors included: downplaying of employees' welfare in mergers and acquisitions, dealing with employee resistance to change under the new reality, loss of job commitment, redundancy, and employee turnover with concomitant loss of key talents, treating human capital as cost, imbalance pay setting and post merger fits (Ugbaka,2004; Adeyemi, 2005; Omokhodion, 2007).

Downplaying of Employees' Welfare in Mergers and Acquisition: Banks that consolidated through mergers and acquisitions did not consider the welfare of their workers in their negotiations. By way of definition, a merger occurs when two or more companies transfer their business and assets to a new company (or to one of themselves); and in consideration their members receive shares in the transferee company. Acquisition takes place when one company acquires sufficient shares in another company so as to give it control of that company. The shareholders of the acquired company are paid off and the acquirer becomes the owner of all or a substantial part of the assets of the acquired company (Akamiokor, 1989). It is on record that the merged and acquired banks, in an effort to meet the requirements of the reforms, relegated the welfare and working conditions of their workers to the background while focusing all attention in meeting the target and deadline of the reform agenda (Akanbi and Oso, 2005).

Dealing with Employee Resistance to Change: Another issue that arose a as result of the banking sector reform is employee resistance to change which management had to contend with. Against the backdrop of the human resources challenges that resulted from the reform exercise, it is natural that employees in the banking industry would be reacting and resisting the changes that threatened their jobs and diminished their bargaining powers. Literature suggests that when employees are faced with precarious situations that threaten their jobs and means of livelihood, they are likely to adopt various measurers to protest and resists such changes (Soloye, 1989; Otobo, 1994; Onyeonoru, 2004; Okafor and Bode-Okunade, 2005). Managements of the banks also had to evolve strategies (some of which were anti-labour) to deal with the situation (Adeluyi, 2004; Omokhodion, 2007).

Loss of Job Commitment: The wind of change that blew across the banking industry between July 2004 and December 2005 made every bank staff apprehensive as no one really know one's fate in the imbroglio. According to Fanimo (2006) in many banks changes in job placements have resulted into serious job cuts and rationalization in 
consolidated and non- consolidated banks. This only serves to make bankers regard their jobs as unstable and this has the tendency to affect employees' level of commitment and this worsen labour turnover in the sector.

Redundancy: The reform exercise created a situation of redundancy especially in these banks that consolidated through mergers and acquisitions. Employees become redundant and hence, rationalized with or without benefits. This affected labour-management relations.

Employee Turnover and Loss of Talents: Another key issue arising from the banking sector reform is employee turnover with its concomitant loss of key talents to other key sectors of the economy. Staff who were not sure of the security of their jobs, and who had opportunities elsewhere, had to leave before they were sent away. Turnover rate is highest among the trained professionals and experienced employees who make inroads into the oil and gas and the telecommunications industries as well as the well established, new high-paying banks. This was a source of worry to banks' management especially, the managements of the older banks. Osaze (2006:14) captures this scenario thus:

...the old generation banks are not insulated from this problem. In fact, they are worried that many of their experienced hands are drifting to well established, new high-paying banks. Related to this is the rapid depletion and poaching of trained bankers into the telecommunications sector. This has created acute shortage of information technology (IT) professionals and experienced managers in banks".

Treating human capital as cost rather than assets: This is against the principle of human capital accounting. There was imbalance pay regime, that is, disparity in pay structure among equally qualified personnel who perform similar jobs, and what Okafor (2009) calls post merger fits, that is, the problems arising as a result of the mergers occasioned by the reform.

Okafor (2009) identifies two more issues of the banking sector reforms: job losses and casualization. Analyzing the effect of the reforms on bank job stability, Okafor (2009) submits that a total of 2296 staff of only merged banks about six, lost their jobs during and after the reform exercise either through lay off, retrenchment, pre-mature retirement or outright sack, with the objective of allowing the the banks to restructure and cut down personnel cost to stay afloat.

Assessing the spate of job losses in the banking sector in the post-consolidation period, an officer of the Trade Union Congress (TUC) said:

In the banking industry the congress is worried about the retrenchment occasioned by the post-consolidation of banking...the exercise is unnecessary, unjustified and causing more miseries to homes. We therefore call on employers of labour in the consolidated banks to exercise caution and stop the retrenchment fever in the banks (Okhomina, 2006:7).

This situation does not augur well for industrial relations climate in the industry. Olaosebikan (2006:29) rightly observes that:

The employer-employee relations in the banking industry have been the worst .... Banks attracted people into their organizations with fat salaries only to destroy and ravage their intellect. First class graduates are turned into zombie by these banks within a few years of employment ... The staff were used and dumped at will without a care for them and the families they supported... even now most of the employees come to work each day unsure if they still had a job.

According to Okafor (2009) the main idea to be drawn from the above assertion is that job losses in the post-consolidation era in Nigerian banking sector is a reality that has come to stay. This reality starring us in the face has serious implications of engendering employee resistance in the sector. In other words, job losses have affected employee relations in the sector negatively.

Another key issue of the reform agenda is that of casualization of labour. According to Okafor (2009) in order reduce cost; particularly training cost, some banks resorted to casualization of labour. Okafor (2009) describes the term as Nigeria's modern day slavery of which banks, oil and gas and telecommunications sectors are the greatest culprits. According to him, these industries shy away from employing staff on a permanent basis owing to their unwillingness to pay staff residual benefits. Casualization is seen as anti-labour and exploitative strategy employed by the banks and other industries to boost their profits at the expense of employees. This undermines good industrial relations (Akanbi and Olesin, 2007).

\section{Challenges Confronting Management and Labour Unions in the Post-Consolidation Banking Industry}

The bank reforms created anxiety and concerns for employees in the sector since they are usually at the receiving end of industry change and reform regimes. The exercise which took the form of mergers and acquisitions resulted in 
downsizing, retrenchment, rationalization, and cost reduction programmes, etc; to enable the banks remain afloat, presented serious challenges to management and the labour unions which resulted into poor industrial relations.

According to (Osaze (2006) the consolidation of banks presents several challenges in the area of integration, lending, survival and future of the various mergers as parts of the technical and professional challenges in the sector. In the area of integration, banks are finding it quite difficult to integrate disparate cultures, information technology processes and systems and staff harmonization. Banks that came out of the consolidation programme as a result of mergers are finding it particularly difficult to achieve seamless integration of their various identities. According to Okafor (2009) several banks are in this dilemma and are yet to solve this problem successfully.

Again, partly due to the ambiguity of the reforms policies and in a bid to remain relevant, some management committed their organizations into merger arrangements that could not stand the test of time. The reality is that most of such arrangements collapsed few years after. A case in point is the Spring Bank situation where the marriage of strange bedfellows (the merger of organizations with different focus and conflicting interests) set the directors against themselves (Okafor, 2009).

The greatest challenges facing the consolidated banks are on the issues of employees' remuneration, staff harmonization and placement and job security. Okafor (2009) maintains that reports on the banks in the post-consolidation era show that management and workers' unions on several occasions are spoilt for war on wage reviews. These agitations, according to him, are based on the enhanced liquidity of the banks as a result of consolidation. Agitations for wage review are persistent in smaller banks that are paying competitive salaries to their workers. Remuneration issue is of great concern to banks, as they are loosing the professionals and experienced hands not only to high paying banks but also to telecommunications industry. This has created acute shortage of information technology (IT) professionals and experienced managers in the banks (Osaze, 2006).

Another serious challenge occasioned by the reforms is job insecurity. Bank job is no longer secure because of changes in placements arising from the reform exercise. In many banks the changes in placement have resulted into serious job cuts and rationalization both in consolidated and non-consolidated banks. Bankers now regard their jobs as unstable. According to Fanimo (2006) job cuts are now continuous in the banking sector and this has the tendency to make employees less committed to their jobs as well as accentuate the already worsen labour turnover in the sector. Again, the employees of the thirteen banks that were unable to meet the requirements of the reforms automatically become jobless as result of the withdrawal of operating licenses from those banks. This is a big challenge not only to management and labour unions, but also to the country as a whole as the labour market is saturated and graduate unemployment remains high.

The reforms in the industry are far from being over. The new reform by CBN coming after the bank consolidation reform still has implications for labour relations. This reform, which Inyang (2010) says is creating a tsunami in the industry, brought about the sack of some bank chief executive officers (some of them charged to court), also resulted in rationalization of bank employees in large numbers.

No category of bank is spared the rod of banking sector reforms. Recently, the searchlight of the reform agenda was beamed on the microfinance banks, and those that could not pass the acid test of the reform had their licenses withdrawn by the CBN. This again implies loss of jobs as the staff of the banks were also thrown out of jobs. All these came as a result of official abuses and mismanagement in the Nigerian banks. Inyang (2010:9) aptly describes the scenario thus: "it is now clear to all that no job was indeed safe in the banks. Heads are still rolling from the monumental mismanagement of the Nigerian banks, not just from the banks with beheaded leadership but from the other banks"

These are serious challenges for management and unions as they have far reaching implications for labour relations in the industry. The reforms have apparently changed the face of industrial relations in the banking industry. There is now deep-seated animosity between management and unions and the basic principles upon which sound industrial relations are founded are jettisoned, thus creating an environment characterized by incessant industrial disputes, affecting the health of the industry (Inyang 2010).

\section{Labour-Management Relations in the Post Reforms era: The Way Forward}

Against the obvious impact of the banking sector reforms on employment relationship based on the issues and challenges raised, and in order to re-establish a robust labour-management relations in the industry, the unions must wake up to re-assert themselves as the vanguard of the working class. This wakeup call according to Inyang (2010) requires labour unions to: 
- Improve their understanding of current development and best practices in labour relations.

- Have deeper knowledge of labour and collective bargaining issues/trends.

- $\quad$ Insist on and improve the employability of their members.

- $\quad$ Sharpen their negotiating skills and improve their effectiveness on the bargaining table.

- $\quad$ Provide quality leadership to handle the issue and face the emerging challenges in the industry.

- $\quad$ Undertake continuous training and re-training of members to handle the post-reform challenges.

- $\quad$ Speak up against any form of mismanagement of organizational resources in the industry.

- $\quad$ Organize mass struggles to change the existing labour laws as transcending mere reforms.

- $\quad$ Resists and challenge casualization of labour

- $\quad$ Struggle for and ensure effective representation at management level where strategic decisions are taken.

- $\quad$ Strive to be strategic business partners in the industry by constantly evaluating the alignment between union activities or practices and the business objectives of the banks.

- $\quad$ Promoting and strengthening internal democracy in their unions.

The management in the banks equally has important responsibilities to perform to enhance good

industrial relations in the industry. These requires then to:

- $\quad$ Regard the human resources (workforce) truly for what they are - the most valuable resource of their organizations.

- $\quad$ Stop treating their human capital as cost but as assets that they really are.

- $\quad$ Ensure effective and proper management of the resources at their disposal. This will forestall the incidence of frequent reforms.

- $\quad$ Ensure the employability of employees not just career advancement.

- $\quad$ Give the employees (through their unions) a voice at the central management level.

- $\quad$ Collaborate with unions to resolve impending labour issues

- $\quad$ Open up the channels of communication and ensure effective communication with unions.

- $\quad$ Make information available to staff and the unions. This will help people take reasonable and timely decisions since information is power.

- $\quad$ Operate an open door policy and be amenable to union suggestions.

- $\quad$ Regard the union not as adversary but as a strategic business partner. This will promote the much desired collaboration in business transactions.

The CBN that initiates these reforms has the responsibility of paying serious attention to the people-issues and to effectively incorporate same into agreements reached between labour and management.

\section{Conclusion}

The banking industry constitutes a strategic sector that drives a nation's economy. The banking system performs the function of financial intermediation and hence, it is the engine of growth in the economy. Reforms in the industry tend to impact on the economy as a whole. The banking sector reforms in Nigeria brought to the fore-front critical issues and challenges for labour-management relations in the industry and these tended to undermine the principles of good industrial relations. The issues and challenges include: job losses, loss of job commitment or low employee morale, redundancy, employee turnover and loss of latents, wage disparity, casualization of labour and wage reduction, as cost cutting strategy accepted in the industry. All these affected labour-management relations during and even in the post reforms era. The wakeup call is for labour unions, and management and the government to re-strategize and confront these challenges in the post-reforms era.

Union leaders can do this by constant training and retraining their members to keep abreast with best practices in labour unionism, enhancing the quality of their leadership as well as promoting and strengthening of union internal democracy, among others. Management on their part should see the union members as their key resources, ensuring effective and proper management of resources, making information available and ensure effective communication, 
being amenable to union suggestions as well as regarding the union as a strategic business partner rather than an adversary, among others. The government, through the CBN, must properly articulate labour issues in reform programmes. It is hoped that if these recommendations are implemented by the parties concerned, future reforms in the banking industry will not result to such challenges that will negatively impact labour-management relations

\section{References}

Adegbaju, A. A. \& Otokoyo, F. O. (2008). Recapitalization and banks performance: A case study of Nigerian banks. African Economic and Business Review, 6(1),1-17.

Adeluyi, A. (2004). Facing new challenges in banking. The Guardian Newspaper (Nigeria), July 16, p.47.

Adeyemi, B. (2005). Bank consolidation and the human capital challenge. The Guardian Newspaper (Nigeria), November 23, pp.33-35.

Akanbi,F. \& Oso, T(2005). $\$ 25$ billion capital base: Will the CBN bend the rule? Sunday Punch (Nigeria), February 6, p.35.

Akanbi, F. \& Olesin, A. (2007). Banks still use casual labour to boost profits. Sunday Punch (Nigeria), June 17, p.12.

Akamiokor, O. (1989). Merger and acquisition: Human capital risk factor in bank consolidation exercise. The Guardian Newspaper (Nigeria), December 20, pp.56-57.

Balogun, E.D. (2007). Banking sector reforms and the Nigerian economy: Performance, pitfalls and future policy option. Retrieved from http://inprub.uni-muenchen.de/3804/

Bain, G. S. \& Clegg, H. A. (1974). A strategy for industrial relations research in Great Britain. British Journal of Industrial Relations, 12(1), 91-113. http://dx.doi.org/10.1111/j.1467-8543.1974.tb00006.x

Fanimo, D. (2006). Consolidation: Union flays sack of bank workers. The Guardian Newspaper (Nigeria), April 18, p.51.

Fashoyin, T. (2005). Industrial relations in Nigeria: Development and practice. $2^{\text {nd }}$ ed. Lagos: Longman.

Inyang, B. J \& Akpama, A. M. (2002). Personnel management practice in Nigeria. Calabar: Merb Publishers.

Inyang, B. J. (2010). Management-labour relations in a competitive industry: Challenges for labour unions. A paper presented at a workshop on management and labour unions: A partnership that work, organized by ALZ Trust. Ltd, Lagos, for members of Association of Senior Staff of Banks, Insurance and Financial Institutions (ASSBIFI) held in Pyramid Hotels, Calabar on $17^{\text {th }}$ October, 2010.

Okafor, E.E. \& Bode-Okunade, A.S. (2005). Introduction to individual and labour relations. Ibadan: Mubak Publishers.

Okafor, E. E. (2009). Post-consolidation challenges and strategies for managing employees' resistance to change in the banking sector in Nigeria. Journal of Social Science, 19(2), 129-139.

Okhomina, O. (2006). TUC chief laments rising cases of job loss. Vanguard Newspaper (Nigeria), April 11, p.7.

Olaosebikan, A. (2006). Advertorial: Alliance of strange bedfellows. Vanguard Newspaper (Nigeria), May 15, pp.28-29.

Omokhodion, 1. (2007). Fallacies of banking consolidation. The Punch Newapaper (Nigeria), August, 13. p10.

Onyeonoru, I.P. (2004). Globalization and trade union resistance. African Journal for the Psychological Study of Social Issues, 7(1),71-98.

Osaze, B. (2006). Merger and acquisition and challenges in the banking sector. Business Day Newspaper (Nigeria), May 11, p.14.

Olobo, O. (1994). Further readings in Nigeria's industrical relations. Lagos: Malthouse.

Soleye, O. (1989). Work and government work. Faculty of social science lecture series. Ibadan: University of Ibadan.

Ugbaka, G. (2004). 25 billion naira capital base: Don identifies defects. Financial Standard (Nigeria), August 30, p.9. 